\title{
Flexural Strength of Reinforced Concrete RAC Beams Exposed to 6-hour Fire - Part 2: Rich Mix
}

\author{
Abdul Hafeez Buller \\ Department of Civil Engineering, Quaid- \\ e-Awam University of Engineering, \\ Science \&Technology, \\ Nawabshah, Sindh, Pakistan \\ ah.buller@quest.edu.pk
}

\author{
Mahboob Oad \\ Department of Civil Engineering, Quaid- \\ e-Awam University of Engineering, \\ Science \& Technology, \\ Nawabshah, Sindh, Pakistan \\ mahbooboad04@gmail.com
}

\author{
Bashir Ahmed Memon \\ Department of Civil Engineering, Quaid- \\ e-Awam University of Engineering, \\ Science \& Technology, Nawabshah, \\ Sindh Pakistan \\ basher_m@hotmail.com
}

\begin{abstract}
In this research work, experimental investigation on flexural strength of reinforced concrete beams exposed to fire for 6-hours at the temperature of $1000^{\circ} \mathrm{C}$ is presented. The beams are made with $50 \%$ replacement of natural coarse aggregates with recyclable concrete aggregates. A total of 12 reinforced concrete beams using 1:1.5:3 mix (rich mix) and 0.54 water-cement ratio were cast. The beams were prepared in two groups. Group 1 beams were prepared with $\mathbf{5 0 \%}$ recyclable aggregates, whereas group 2 beams were cast with all-natural aggregates (control specimens). All beams were exposed to fire at the abovementioned temperature followed by testing in universal load testing machine under central point load. Comparison of the results reveals that proposed beams show comparable resistance even after exposed to 6-hours fire at $1000^{\circ} \mathrm{C}$.
\end{abstract}

Keywords-fire effect; flexural strength; recycled concrete aggregates

\section{INTRODUCTION}

For many years the search of alternative ingredients of concrete and of ways and means for proper disposal of construction and demolishing waste remained active among researchers and construction industry. A way of tackling both of these issues is by making use of demolishing and construction waste in new concrete. To this end, several attempts [1-3] have been made successfully to utilize demolishing waste as partial or full replacement of fine and coarse aggregates. As coarse aggregates occupy the most volume of the concrete body, replacement of natural coarse aggregates with recyclable concrete aggregates may solve the problem of demolishing waste treatment to a large extent [4]. The theme has been studied to a certain degree but still a lot of work is required to understand the behavior of the material. Fire is one of the hazards a structure might face during its service life. Therefore, the response of recyclable aggregates when exposed to fire should be understood not only to design a fire-resistant structure but also to help in taking decisions about rehabilitation and retrofitting after fire. In this regard, author in [5] presented a literature review about the effect of high temperature on both normal and high-strength concrete subjected to elevated temperatures, whereas, authors in [6] presented a review on the mechanical properties of concrete made with partial and full replacement of natural coarse aggregates, particularly compressive strength after fire. They concluded that a great deal of work is required to improve the confidence about the behavior of concrete with recycled concrete as coarse aggregates. In [7], authors presented a literature review about the use of old concrete for the period 2005-2014. They organized their work in three parts, i.e. use of RAC in steel composite sections, reinforced concrete and longterm performance including fire resistance of composite members. They reported that reinforced composite members have slightly lower or similar structural behavior with certain replacements of natural coarse aggregates with recycled coarse aggregates. Therefore, steel composite members with recycled aggregates can be applied in structural applications.

Authors in [8] experimented on the mechanical properties of concrete with recycled concrete as coarse aggregates used $20 \%, 50 \%$ and $100 \%$ replacement of conventional coarse aggregates. Concrete specimens were exposed to fire at $400^{\circ} \mathrm{C}$, $600^{\circ} \mathrm{C}$ and $800^{\circ} \mathrm{C}$ for 1 hour. Comparison of results of compressive strength, tensile strength and modulus of elasticity with those of conventional concrete showed that there was no difference in thermal response and post fire mechanical properties. In another study for the probable use of waste rubber as partial replacement of coarse aggregates, authors in [9] studied the effect of fire on proposed concrete at temperature and duration same like in [8]. Based on the comparison of the results of proposed concrete specimen with those of conventional concrete, authors concluded that although the properties of proposed concrete specimens were affected, particularly at high temperatures yet the use of the material is possible in new concrete. Authors in [10] used plastic and glass as replacements of fine aggregates and old crushed concrete as replacement of natural coarse aggregates to study the basic properties of concrete. Based on the findings of their research they concluded that the wastes mentioned above can successfully be used in new concrete without compromising of the basic properties of the concrete.

Author in [11] presented details regarding factors affecting the fire response of concrete structural members. It was reported that thermal and structural behavior of concrete particularly spalling of high-strength-concrete depends on various factors. Although good information about thermal and

Corresponding author: A. H. Buller 
structural behavior for normal and high strength concrete is available, yet little information is available for new of fire damaged and rehabilitated reinforced concretes i.e. selfcompacting concrete. Author concludes that considerations should be given to batch mixing, heating rate, loading level etc. to ensure proper performance of concrete with respect to its exposure to fire. Authors in [12] conducted research to prepare guidelines to determine fire safety provisions of old structures of age 50 years and more. They proposed that combined structural and fire engineering provisions should be used to mitigate the risk of concrete spalling. Towards controlling of spalling of high-performance-concrete exposed to high temperature authors in [13] conducted experimental evaluations of compressive, tensile, flexural strength and modulus of elasticity of high-performance air-entrained concrete, polypropylene fiber-reinforced concrete and reference concrete having constant $\mathrm{w} / \mathrm{c}$ ratio. The samples were exposed to $300^{\circ} \mathrm{C}, 450^{\circ} \mathrm{C}$ and $600^{\circ} \mathrm{C}$ and tested. Based on the obtained results authors concluded that both polypropylene fiber concrete and air entered concrete perform well. Authors in [14] studied flexural performance of slabs and beams. They used 5 two-span RC slabs and 7 two span RC beams in their study. Beams and slabs were tested for fire duration in accordance with ISO 834 then CFRP strengthening was applied to the RC members. The specimens were then loaded till failure. The results showed that flexural capacity of the members decreased with increased fire duration. They also observed that fire had more effect on flexural rigidity than bearing capacity of the members. The results revealed that the bearing capacity of the rehabilitated members exceeded that of reference concrete members but rehabilitation had little effect on the recovery of their flexural rigidity. In a study to evaluate the effects of elevated temperature on green concrete, authors in [15] tested concrete specimens cast with $0 \%, 15 \%$ and $30 \%$ replacement of natural aggregates with aggregates from old concrete exposed to fire for 2 hours at $100^{\circ} \mathrm{C}-600^{\circ} \mathrm{C}$. They reported that optimum replacement of natural coarse aggregates to yield maximum strength is $15 \%$ at $450^{\circ} \mathrm{C}$. Test specimens showed hairline cracks in concrete even when exposed to fire, therefore, they concluded that with the above mentioned optimum values the performance of green concrete is in good agreement with natural concrete.

Looking at the state-of-the-art, it is clear that a good deal of work is still required for the subject matter. This motivates the research presented in this paper. In this research, experimental evaluation of the effects of 6-hour fire on rich mix reinforced concrete beams made with recyclable concrete was carried out. Natural coarse aggregates were replaced with demolished concrete aggregates in $50 \%$ proportion. To compare the results, an equal number of reinforced concrete beams with all-natural aggregates was cast. The beams were exposed to fire $\left(1000^{\circ} \mathrm{C}\right)$ for 6 hours. Flexural strength of all beams under central point load was tested in a universal load testing machine. The comparison of the results shows good resistance of the proposed beams against 6-hour fire duration. Therefore, demolished concrete can be used as coarse aggregates in new concrete. It is worth mentioning that this research work is a part of a continuity of a project on the subject matter. Experimental investigations of normal mix concrete are in the process of publication.

\section{MATERIALS AND DESIGN}

Large blocks of demolished concrete were collected from the waste of a commercial 60 -year-old office building. These large blocks were manually hammered down to approximate size of $20 \mathrm{~mm}$, followed by sieve analysis of both recyclable aggregates and natural aggregates in standard fashion. The comparison of sieve analysis of both aggregates is shown in Figure 1. Six reinforced concrete beams of $900 \mathrm{~mm} \times 150 \mathrm{~mm} \times 150 \mathrm{~mm}$ size were cast with $1: 1.5: 3 \mathrm{mix}$ and 0.54 water-cement ratio. In these beams $50 \%$ natural coarse aggregates were replaced with recyclable concrete aggregates [2]. These beams are referred as RAC beams. In addition, 6 RC beams with all-natural aggregates were also cast. These beams are referred as control specimen and are used to compare the results. Two \#4 bars in both tension and compression zones were used along with \#3 bars as stirrups at $150 \mathrm{~mm}$ center to center throughout the length to reinforce the beams. The proposed beams were designed in accordance with [16] which ensures the durability of the member during service life. After casting the beams in standard fashion, all beams were fully immersed in water for 28-day curing. After the elapse of curing time the beams were left in the laboratory for 24 hours to air dry. Then, all beams were exposed to fire in a purpose made oven for 6 hours at $1000^{\circ} \mathrm{C}$. The beams were then left in the oven for 24 hours to avoid damage due to abrupt temperature change. Finally, all the beams were tested in a universal load testing machine with central point load for flexural strength as per ASTM recommendations. Load, deflection and cracking in beams were carefully monitored at regular intervals. Loaddeflection of both RCA beams and NCA beams is plotted in Figures 2 and 3 .

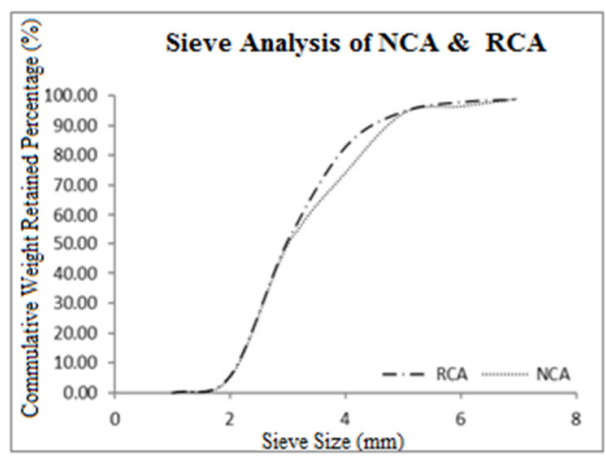

Fig. 1. Gradation of aggregates

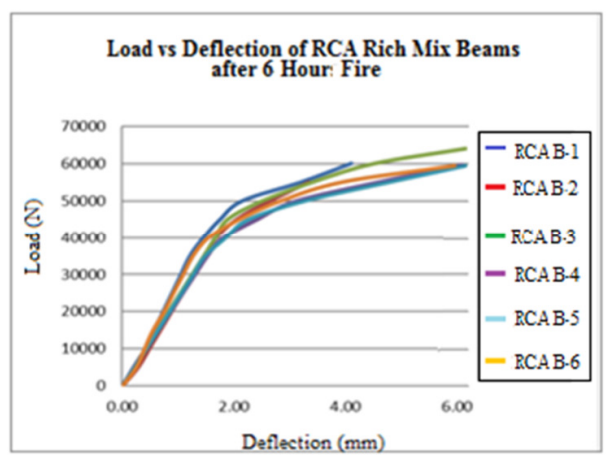

Fig. 2. Load vs deflection of RCA beams 


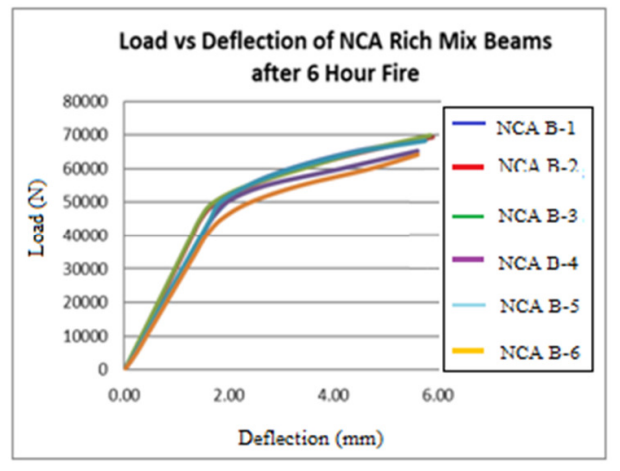

Fig. 3. Load vs deflection of NCA beams

\section{RESULTS AND DISCUSSION}

Figure 1 shows that both recyclable concrete aggregates and natural aggregates used in the concrete mix are well graded with approximately the same pattern. Figures 2 and 3 show the load-deflection behavior of both beam groups. It may be observed that within the group of beams and in comparison to each other the trend of load and deflection increase is almost symmetrical with the exception that RCA beams showed more deflection and ruptured at load less than NCA beams. Flexural strength is computed from the maximum load at which beams fail. Table I gives the average values of load, deflection and flexural strength of both beam groups. Figure 4 shows the comparison of flexural strength of all beams.

TABLE I. AVERAGE VALUES OF ALL BEAMS

\begin{tabular}{|c|c|c|c|}
\hline Description & NCA-beams & RCA-beams & Difference (\%) \\
\hline Load $(\mathrm{N})$ & 67668 & 62091 & 8.24 \\
\hline Deflection $(\mathrm{mm})$ & 5.74 & 6.03 & 5.1 \\
\hline Flexural strength $(\mathrm{MPa})$ & 27.07 & 24.84 & 8.24 \\
\hline
\end{tabular}

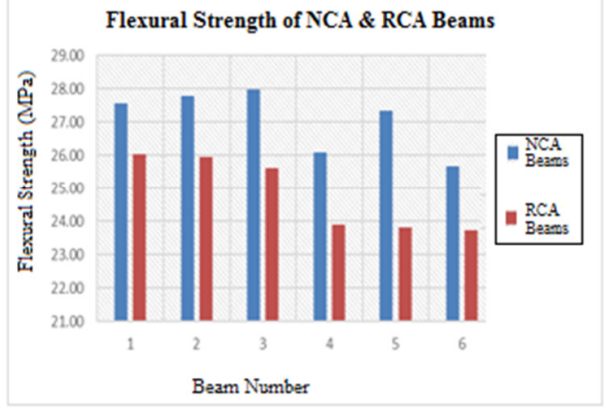

Fig. 4. Flexural strength of all beams

From Table I it is observed that the proposed reinforced concrete beams showed $8.24 \%$ reduction in flexural strength and $5.1 \%$ increase in deflection in comparison to control specimens. These values are less than $10 \%$ which shows good fire resistance of the proposed concrete beams. Cracking in the beams during loading process was monitored carefully. Selected beams of natural aggregates and recyclable aggregates are shown in Figures 5 and 6 respectively. It is observed that almost all beams failed in shear with diagonal cracks initiating from loading location towards supports. This also validates the use of the proposed aggregates in rich mix concrete.

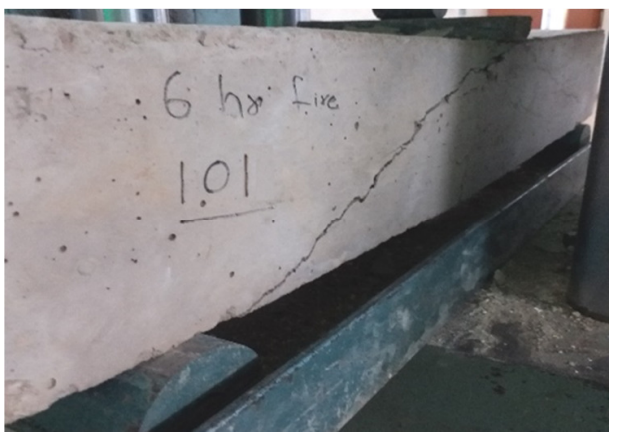

Fig. 5. Cracking in a NCA beam

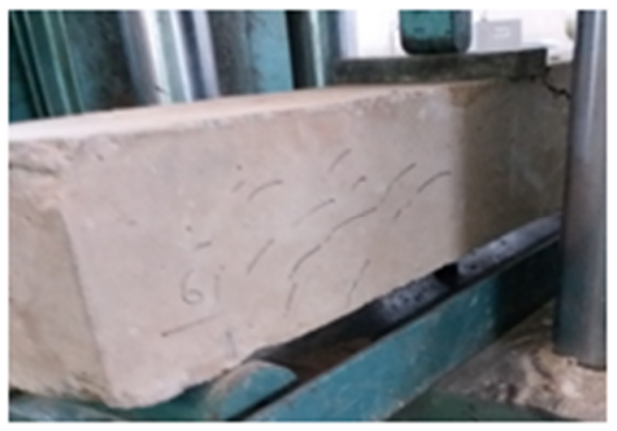

Fig. 6. Cracking in a RCA beam

\section{CONCLUSION}

This paper presents the experimental evaluation of the effects of 6-hour fire on rich mix reinforced concrete beams made with $50 \%$ replacement of natural coarse aggregates with recyclable aggregates from old demolished concrete. A total of $12 \mathrm{RC}$ beams were cast using rich mix and were cured for 28 days. Out of these beams, half of the specimens were cast with all-natural aggregates to compare the results. All the beams were exposed to fire for a 6-hour duration at $1000^{\circ} \mathrm{C}$ followed by central point load testing in a universal load testing machine. Load, deflection, and cracking were monitored at regular intervals. Result comparison shows that both deflection and flexural strength of proposed specimens exhibited less than $10 \%$ reduction (all beams failed in shear testing). This proves the effective use of proposed aggregates in rich mix concrete without compromising much on the flexural strength of concrete.

\section{SUGGESTIONS}

This paper used a limited number of beams and two commonly used concrete mixes with water cement ratio of 0.54 . However, it is suggested that more beams, with different water-cement ratios, could be used. It is also suggested that the experimental work on the issue may be augmented with theoretical analysis regarding different concrete parameters, checking of the experimental results and establishing a theoretical frame for concrete with demolished concrete as aggregates.

\section{REFERENCES}

[1] A. A. Bhatti, B. A. Memon, "Strength, Deflection and Cracking Behavior of Concrete Slab Using Demolished Concrete as Coarse Aggregates", International Journal of Engineering Sciences \& Research Technology, Vol. 3, No. 6, pp. 492-506, 2014 
[2] M. Oad, B. A. Memon, "Compressive Strength of Concrete Cylinders using Coarse Aggregates from Old Concrete", 1st National Conference on Civil Engineering (NCCE 2013-14)-(Modern Trends and Advancements), April 28-29, 2014

[3] A. H. Buller, B. A. Memon, "Effect of Fire on Strength of Concrete Cubes with RCA as Coarse Aggregates", 1st National Conference on Civil Engineering (NCCE 2013-14)-(Modern Trends and Advancements), April 28-29, 2014

[4] B. A. Memon, "Recent Development on Use of Demolished Concrete as Coarse Aggregates", International Journal of Emerging Technology and Innovative Engineering, Vol. 2, No. 1, pp. 1-11, 2016

[5] D. J. Naus, The Effect of Elevated Temperature on Concrete Materials and Structures - A Literature Review, US Nuclear Regulatory Commission, Office of Nuclear Regulatory Research, Washington, 2006

[6] D. Cree, M. Green, A. Noumowe, "Residual Strength of Concrete Containing Recycled Materials after Exposure to Fire: A Review", Construction and Building Materials, Vol. 45, pp. 208-223, 2013

[7] W. G. Li, J. Z. Xiao, C. J. Shi, C. S. Poon, "Structural Behavior of Composite Members with Recycled Aggregates Concrete - an Overview", Advances in Structural Engineering, Vol. 18, No. 6, pp. 919938,2015

[8] J. P. B. Vieira, J. R. Correia, J. de Brito, "Post-fire Residual Mechanical Properties of Concrete made with Recycled Concrete Coarse Aggregates", Cement Concrete Research, Vol. 41, No. 5, pp. 533-541, 2011

[9] A. M. Marques, J. R. Correia, J. de Brito, "Post-Fire Residual Mechanical Properties of Concrete made with Recycled Rubber Aggregate", Fire Safety Journal, Vol. 18, pp. 49-57, 2013

[10] M. Batayneh, I. Marie, I. Asi, "Use of Selected Waste Materials in Concrete Mixes", Waste Management, Vol. 27, No. 12, pp. 1870-1876, 2007

[11] V. Kodur, "Properties of Concrete at Elevated Temperatures", ISRN Civil Engineering, Vol. 2014, ArticleID 468510, 2014

[12] G. Wang, D. Barber, P. Johnson, M. C. Hui, "Fire Safety Provisions for aged Concrete Building Structures", Procedia Engineering, Vol. 62, pp. 629-638, 2013

[13] T. Drzymała, W. Jackiewicz-Rek, M. Tomaszewski, A. Kus, J. Galaj, R. Sukys, "Effects of High Temperature on Properties of High Performance Concrete (HPC)", Procedia Engineering, Vol. 172, pp. 256-263, 2017

[14] J. T. Yu, Y. Liu, Z. D. Lu, K. Xiang, "Flexural Performance of Fire Damaged and Rehabilitated Two Span Reinforced Concrete Slabs and Beams", Structural Engineering and Mechanics, Vol. 42, No. 6, pp. 799813,2012

[15] M. A. Salau, O. J. Oseafiana, T. O. Oyegoke, "Effects of Elevated Temperature on Concrete with Recycled Coarse Aggregates", IOP Conference Series: Materials Science and Engineering, Vol. 96, ArticleID 012078, 2015

[16] American Concrete Institute, ACI 318-05, Building Code Reqirement for Strucrural Concrete, ACI, 2005 